\title{
Exchange Rate Pass-Through Investigation for Turkish Economy
}

\author{
Erdoğan Kotil ${ }^{*}$ \\ Department of Economics, Faculty of Economics and Administrative Sciences, Bolu Abant Izzet Baysal University, Bolu, \\ Turkey
}

Turkish economy continued to rapidly open up in the last 40 years. It has long been in the top 20 largest economies in the world. Exchange rate is an important variable affecting micro and macro variables in the economy. This study aims to investigate the effect of exchange rate changes on the producer and consumer prices in Turkey by using the VAR model. Results show the degree of transition with effect-response functions and how the prices were affected by variance decomposition by using the 2005-2019 monthly data. CPI's response to the change in nominal exchange rate was found to be greater than PPI. The end of the impact is shorter than CPI's impact.

Keywords: pass-through, inflation, exchange rate, VAR model, substitute goods

\section{OPEN ACCESS}

Edited by:

Simon Grima,

University of Malta, Malta

Reviewed by:

Nihat Dağistan,

Başkent University, Turkey Selahattin Togay,

Gazi University, Turkey Aykut Şarkgüneşi,

Bülent Ecevit University, Turkey

*Correspondence:

Erdoğan Kotil kotil_e@ibu.edu.tr

Specialty section:

This article was submitted to

Mathematical Finance,

a section of the journal

Frontiers in Applied Mathematics and

Statistics

Received: 13 November 2019 Accepted: 10 December 2019 Published: 24 January 2020

Citation:

Kotil E (2020) Exchange Rate

Pass-Through Investigation for

Turkish Economy.

Front. Appl. Math. Stat. 5:66

doi: 10.3389/fams.2019.00066

\section{INTRODUCTION}

In an open and highly integrated economy, the exchange rate affects most of the macroeconomic variables. Openness of the Turkish economy has accelerated dramatically since the January 24 , 1980, program. For example, the share of Turkey's foreign trade volume in GDP realized in 1980, 2000, and 2018 was 6, 16, and 31\%, respectively. The depreciation of TL (Turkish Lira) mainly affects prices in two ways. These are the increase in the cost of imports in terms of TL and consequently the increase in prices of imported inputs.

The effect of exchange rate changes on domestic prices in an open economy is known as ERPT (Exchange Rate Pass-through). In macroeconomic terms, the level of ERPT is closely linked to monetary policy, as it directly affects inflation rates. In a microeconomic level, the degree of pass-through determines how firms and households are affected by external shocks [1].

Graphs 1, 2 show the relationship between exchange rate and CPI (consumer price index) in the period 2005-2019. These two variables show the importance of ERPT in Turkey in micro and macro levels.

If the exchange rate changes cause the same changes in domestic prices, the transition effect is complete. If it is reflected at a lower rate, the transition effect is considered incomplete. In other words, ERPT is complete when most of the exchange rate movement is transferred to domestic prices.

According to PPP (purchasing power parity), the main reason for the change in exchange rates is the different inflation rates of countries. The thought behind this is the LoP (law of one price). LoP is the equalization prices of the same goods when they are expressed as the same currency. LoP applies in a world where competition is complete and there are no barriers to entry. The LoP establishes a one-to-one relationship between the domestic price of commercial goods and the foreign price of identical goods [2]. This means that the transition is complete. If the purchasing power parity is valid, the pass-through effect is complete. In perfect competition markets where there is no break, the pass-through effect will be complete as the profit margin for exporters will be zero. Therefore, studies have focused on why ERPT is not complete [3]. However, the effect 

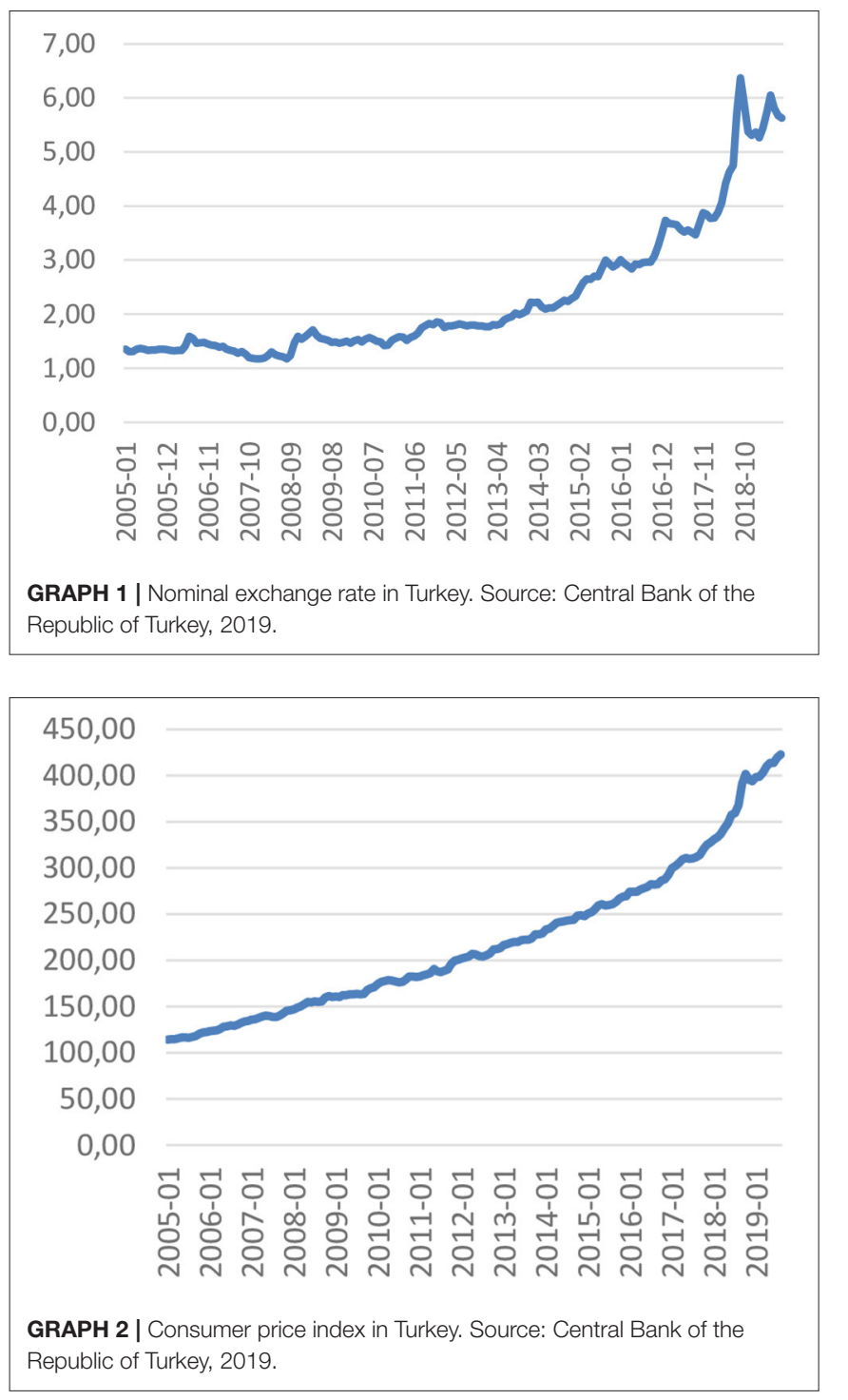

of pass-through to consumer prices is uncertain and depends on the rate of pass-through to import prices, the share of imports in the consumption, demand conditions, the cost of adjusting prices, and the duration of the depreciation [5].

The incomplete ERPT is usually related with these factors such as trade barriers, transaction, and transport costs, market power of the firm, and lack of complete substitution between domestic and foreign products. Numerous reasons for low pass-through effect are found in the literature. One or more of these causes together causes the ERPT to be incomplete.

One of the first explanations of the incomplete pass-through effect is based on the market share of firms. Accordingly, firms change their profit margins in order not to lose their market share [6]. In a market where imperfect competition conditions apply and where firms make mark up pricing against the exchange rate, the incomplete ERPT emerges [7]. Differences in ERPT vary in countries with high exchange rate volatility, but also due to changes in the composition of imports [8].
Slow adjustment of nominal prices may lead to a low passthrough effect in countries with low inflation [9]. As a result of globalization, the fact that most of the production processes take place in different countries causes the cost to be formed in different currencies, and this causes the pass-through effect to be incomplete [10]. The high level of pass-through effect is also related to the frequency of price adjustment [11]. The fact that exchange rate shocks remain under inflation in inflation targeting regimes is also seen as the reason for low pass-through effect [12].

The rest of the study is arranged as follows: Section Literature presents an overview of the literature. The pass-through effect mechanism is discussed in section Mechanism of Pass-Through. Data and methodology of the baseline model are discussed in section Data and Method. We forecast VAR model in section Empirical Results, and finally, this study provides a discussion of the main results and highlights some policy implications.

\section{LITERATURE}

There are many studies on ERPT in the economic literature. Empirical studies have begun to be conducted on developed economies and have recently increased rapidly for developing countries. Basically, the literature is concentrated on two points. The first point is focused on factors affecting the transition effect. The second is related with the magnitude and duration of the pass-through. There have been many studies investigating the magnitude of the effect of exchange rate volatility on prices for the last two decades. The results obtained differ due to the variables used in these studies, the periods covered by the data, and the different monetary policies in the countries where the studies were conducted [13].

McCarthy [14] examined the pass-through effect using the VAR model for nine industrialized countries. The variables used in the study are oil prices, output gap, import price, exchange rate, PPI (producer price index), and CPI. In this study, it is concluded that the pass-through effect is high in countries with high share of imports in foreign trade.

Ito and Sato [15] investigated the pass-through effect with the VAR model for East Asian countries by using 1993-2005 data. The variables are oil price, output gap, money supply, nominal exchange rate (NERT), and domestic prices. Then, they added PPI and CPI to these variables and developed the model. The main results of the study are that the pass-through effect of the exchange rate to import prices is quite high in the economies affected by the crisis and the transition to CPI is low except for one country.

Helmy et al. [16] conducted VAR analysis with six variables with the data of 2003-2015 in Egypt. The variables are food price index, NERT, industrial production index (IPI), PPI, CPI, and import prices. In the study, it was found that the exchange rate pass-through effect was incomplete for all three price indices. However, the transition effect is relatively lower in CPI.

Leigh and Rossi [17] examined the VAR analysis with 19942002 data for Turkey. They found that the change in the exchange rate to PPI was higher than the pass-through effect to CPI and that the pass-through effect was felt in the first 4 months. 
Campa and Goldberg [8] found that the pass-through effect of exchange rate was shorter in 23 OECD member countries. They found that the effect from short-term to long-term increased.

Ponomarev et al. [18] found that the reflection is between 5 and $15 \%$ and decreases with time in their VAR analysis for Russia with the data of 2000-2012.

Ito and Sato [19] have used the VAR model with data from 1990 to 2006 for some countries of East Asia, Latin America, and Turkey. They indicate that the pass-through effect is quite high in Turkey and some other countries.

Alptekin et al. [13] found incomplete pass-through effect using VAR analysis in the 2005-2015 period. They found that the CPI's response to a one-unit change in the exchange rate was lower than that of the PPI.

Kara and Ögünç [20] found that the exchange rate passthrough effect was low by using the VAR model with the data of the 2002-2011 period. They found that the pass-through effect was reduced over time.
Kaygisiz [21] established the VAR model using 2002 2016 monthly data. He used PPI, NERT, IPI, money supply, and oil prices data. He found low pass-through effect for Turkey and the effect remained constant during the period.

Dereli [22] found that the real exchange rate has a high passthrough effect on CPI for Turkey by using VAR analysis with 2005-2017 data.

\section{MECHANISM OF PASS-THROUGH}

The mechanism is shown in Figure 1. The pass-through effect of the exchange rate to domestic prices can occur in two ways. The first is the direct effect. Accordingly, the change in the exchange rate increases the cost of production by making imported inputs more expensive. At the same time, the prices of the imported finished goods increase; thus, it leads to an increase in domestic prices aggregately, which is measured by CPI. The second effect

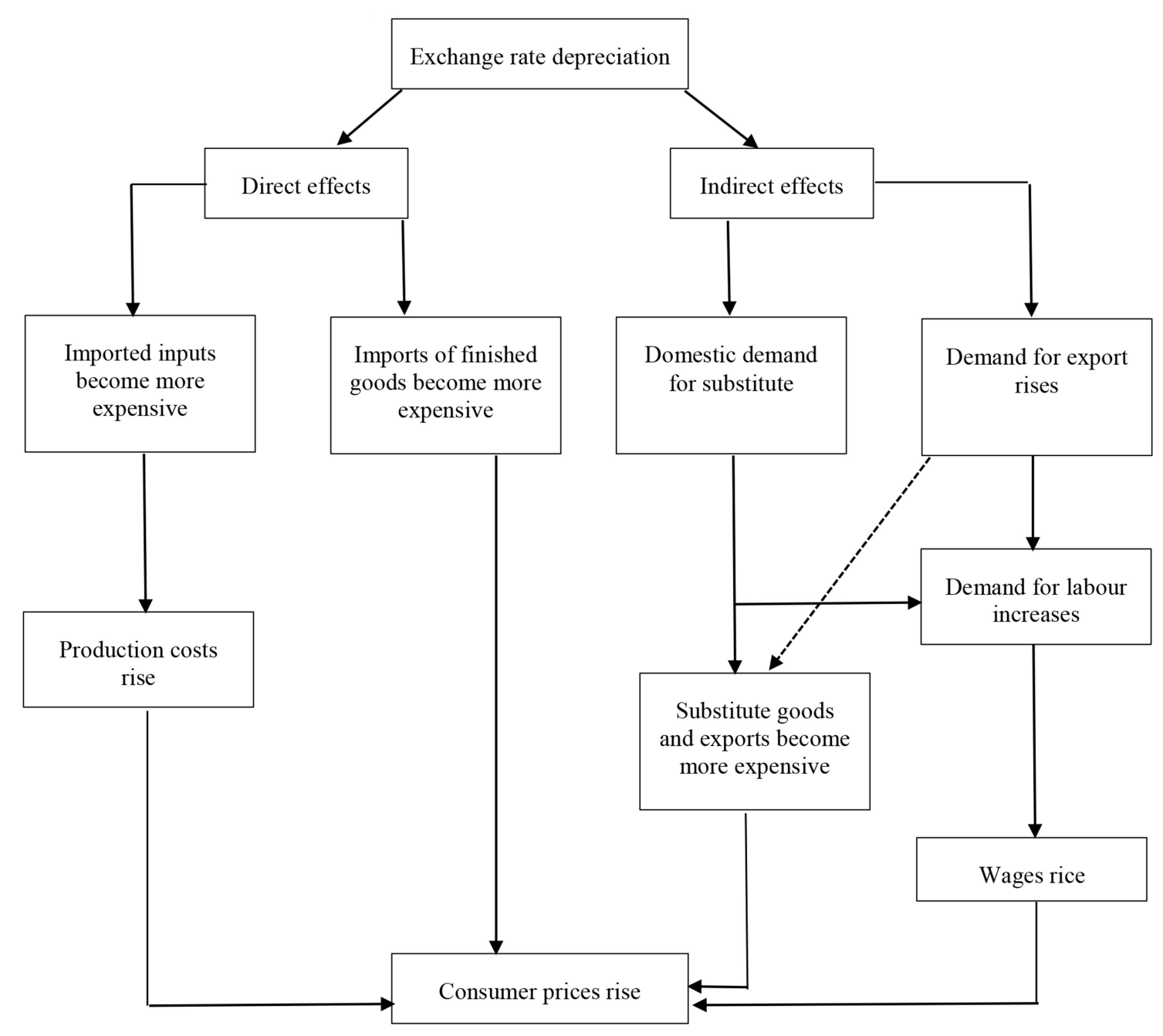

FIGURE 1 | Mechanism of pass-through. Source: Schröder and Hüfner [4], p. 4. 
relates with the competitiveness of goods in foreign markets. The depreciation of national currency makes domestic goods cheaper in foreign markets. This situation increases domestic prices by increasing exports and aggregate demand. The increase in domestic prices reduces reel wages. It also increases production. When real wages fall to their previous level, production costs, and price level will increase. In addition, production will decrease [4].

\section{DATA AND METHOD}

McCarthy's [14] model is used as the basis of this study in which the change of exchange rate to producer prices and consumer prices is investigated.

The VAR model is a multidimensional time series model in which all variables included in the model are defined by their own and other variables with lag values.

TABLE 1 | Unit root test results.

\begin{tabular}{lcc}
\hline Variable & $\boldsymbol{t}$ - Statistic & $\boldsymbol{P}$-value \\
\hline $\mathrm{D}(\mathrm{LIPI})$ & $-2.418627^{\star *}$ & 0.0155 \\
$\mathrm{D}(\mathrm{LNERT})$ & $-10.03363^{\star}$ & 0.0000 \\
$\mathrm{D}(\mathrm{LPPI})$ & $-8.551752^{\star}$ & 0.0000 \\
$\mathrm{D}(\mathrm{LCPI})$ & $-10.17146^{*}$ & 0.0000
\end{tabular}

*, ** denotes statistical significance at 1 and $5 \%$.

TABLE 2 | Variance decomposition of DLPPI.

\begin{tabular}{lccccc}
\hline Period & S.E. & DLIPI & DLNERT & DLPPI & DLCPI \\
\hline 1 & 0.011858 & 0.100446 & 33.82081 & 66.07874 & 0.000000 \\
2 & 0.014899 & 0.095067 & 47.48739 & 51.67575 & 0.741794 \\
3 & 0.015138 & 0.093274 & 46.22238 & 50.87628 & 2.808061 \\
4 & 0.015182 & 0.256125 & 46.01125 & 50.78603 & 2.946594 \\
5 & 0.015207 & 0.287332 & 45.87363 & 50.64058 & 3.198458 \\
6 & 0.015229 & 0.315267 & 45.74917 & 50.55772 & 3.377837 \\
7 & 0.015263 & 0.314397 & 45.56766 & 50.34228 & 3.775661 \\
8 & 0.015272 & 0.369108 & 45.52371 & 50.33178 & 3.775393 \\
9 & 0.015281 & 0.377219 & 45.50257 & 50.28971 & 3.830504 \\
10 & 0.015284 & 0.377980 & 45.48589 & 50.27047 & 3.865657 \\
\hline
\end{tabular}

TABLE 3 | Variance decomposition of DLCPI.

\begin{tabular}{lccccc}
\hline Period & S.E. & DLIPI & DLNERT & DLPPI & DLCPI \\
\hline 1 & 0.007364 & 2.424792 & 12.91501 & 10.94565 & 73.71454 \\
2 & 0.008512 & 2.863307 & 22.94462 & 18.75845 & 55.43363 \\
3 & 0.008867 & 3.473928 & 22.72838 & 17.39159 & 56.40610 \\
4 & 0.008963 & 4.449338 & 22.72403 & 17.61890 & 55.20773 \\
5 & 0.009125 & 5.435332 & 22.22104 & 17.05781 & 55.28582 \\
6 & 0.009209 & 6.000904 & 22.74835 & 16.93834 & 54.31241 \\
7 & 0.009337 & 5.848119 & 22.25959 & 16.50492 & 55.38737 \\
8 & 0.009367 & 5.837150 & 22.12847 & 16.92435 & 55.11003 \\
9 & 0.009409 & 6.446036 & 21.93775 & 16.79809 & 54.81813 \\
10 & 0.009416 & 6.479824 & 21.98274 & 16.77328 & 54.76415
\end{tabular}

The study used the matrix of VAR approach by McCarthy [14]:

$$
Y_{t}=w_{o}+\sum_{i=1}^{n} \beta_{i} Y_{t-i}+u_{t}
$$

where $Y_{t}$ denotes four vectors of IPI, NERT, PPI, and CPI. $w_{o}$ is intercept, $\beta_{i}$ is coefficient of matrices $4 \times 4$, and $u_{t}$ is the error term.
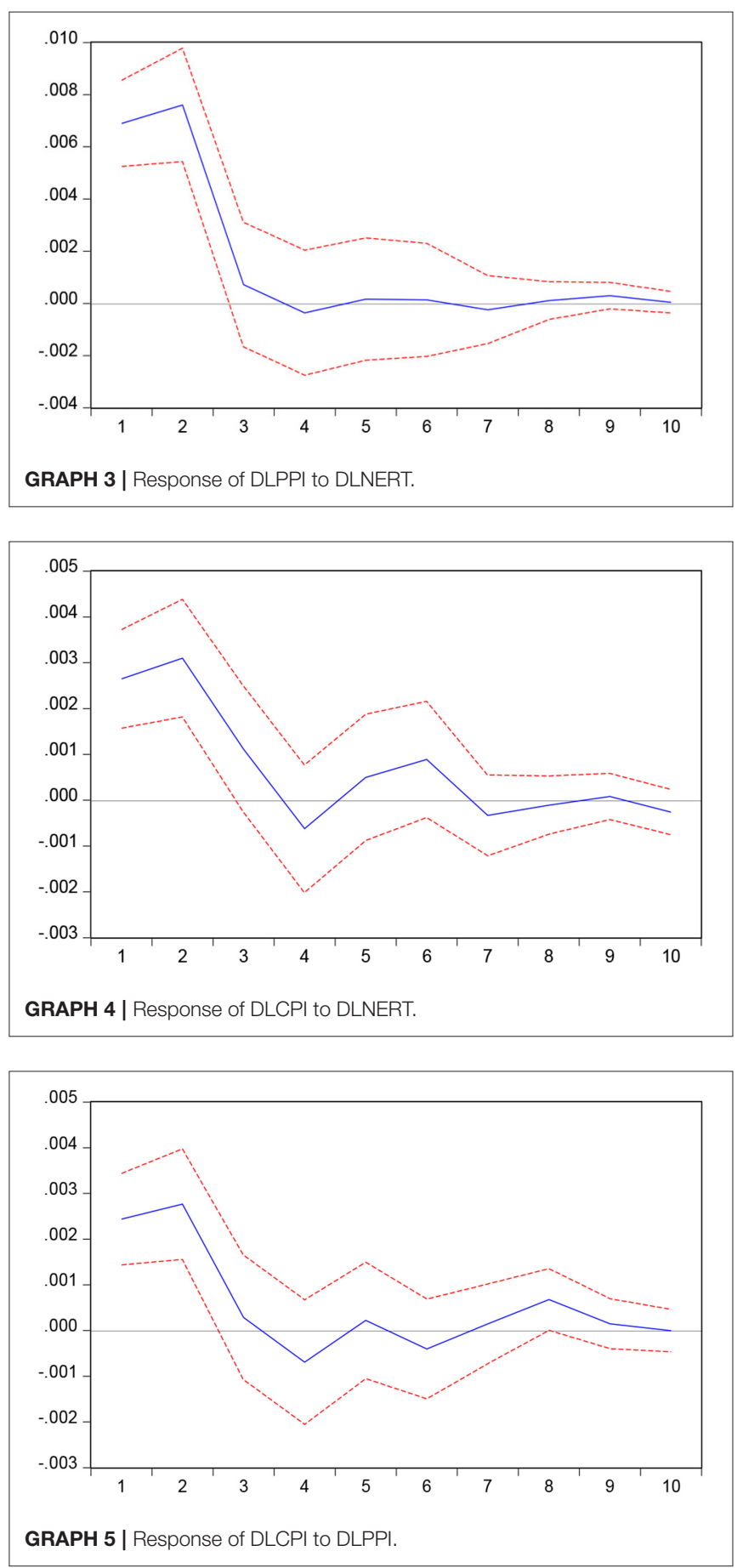
Monthly data between January 2005 and August 2019 were used in the model. The variables used in the study are output gap, NERT, PPI, and CPI. IPI was used to represent the output gap variable. NERT is used in monthly average TL/USD format. The reason for using dollars is that most of the imports are made in dollars. The data were taken from the database of the Central Bank of the Republic of Turkey and converted into logarithmic values.

\section{EMPIRICAL RESULTS}

The VAR model is used in this study, which examines the passthrough effect to the exchange rate of the domestic prices in Turkey. Firstly, the stationarity of the variables was investigated by unit root test. VAR estimation was made by finding the lag length. Impulse-response function and variance decomposition were obtained from VAR estimates.

\section{Unit Root Test}

Table 1 shows the stationarity test results of the variables according to the ADF test. Accordingly, all variables were not stationary at the level but the first differences.

\section{Impulse-Response Function}

Graphs 3, 4 show the responses of the PPI and CPI to the shock in NERT, respectively, while Graph 5 shows the response of the CPI to the shock in the PPI. Accordingly, PPI reacts against one unit shock in the exchange rate by approximately $10 \%$ in the second period and the pass-through effect ends in the fifth period.

CPI response to one unit shock in exchange rate is lower than PPI. The pass-through effect was $5 \%$ in the second period and ended after the eighth period.

The effect of PPI on CPI ends at the end of the third month. Comparing PPI and CPI responses to NERT, PPI's response is greater than CPI.

\section{Variance Decomposition Results}

Forty-six percent of the variance in PPI is explained by the NERT. The effect ends in 3-4 months. The reasons for the change in PPI are PPI, NERT, CPI, and LIPI, respectively (Tables 2 and 3).

\section{REFERENCES}

1. Berner E. Exchange rate pass-through: new evidence from German micro data. Int Econ. (2010) 124:75-100. doi: 10.1016/S2110-7017(13)6 0020-7

2. Kabundi A, Mbelu A. Has the exchange rate pass-through changed in South Africa? South Afr J Econ. (2018) 86:339-60. doi: 10.1111/saje.12197

3. Krugman PR. Is free trade passe?. J Econ Perspect. (1987) 1:131-44. doi: $10.1257 /$ jep.1.2.131

4. Schröder M, Hüfner FP. Exchange Rate Pass-Through to Consumer Prices: A European Perspective (No. 02-20). ZEW Discussion Papers (2002).

5. Savoie-Chabot L, Khan M. Exchange Rate Pass-Through to Consumer Prices: Theory and Recent Evidence. No. 2015-9. Ottawa, ON: Bank of Canada Discussion Paper. (2015).

6. Krugman PR. Pricing to Market When the Exchange Rate Changes (No. w1926). Cambridge, MA: National Bureau of Economic Research (1986).

7. Dornbusch R. Exchange rate and prices. Am Econ Rev. (1987) 77:93-106.
While $22 \%$ of the variance in CPI results from the NERT, the effect ends in 2 months.

\section{CONCLUSION}

The pass-through effect of exchange rate to prices was investigated in this study by using the VAR model with the 20052019 data. The effect of change in the exchange rate was found to be higher in the PPI compared to the CPI. It was observed which asserts that the pass-through effect was completed in a short time. This supports Krugman's approach. Firms do not change immediately the prices when exchange rate changes, resulting in lower CPI pass-through. This can also be explained in part by the substitution effect. The increase in import prices leads consumers to import substitution goods. There is a lower cost increase in these goods, which explains the lower transition in CPI.

\section{DATA AVAILABILITY STATEMENT}

Publicly available datasets were analyzed in this study. These data can be found here: Central Bank of the Republic of Turkey Data Central (https://evds2.tcmb.gov.tr/index.php?/ evds/serieMarket).

\section{ETHICS STATEMENT}

No human studies are presented in this manuscript.

\section{AUTHOR CONTRIBUTIONS}

The author confirms being the sole contributor of this work and has approved it for publication.

\section{ACKNOWLEDGMENTS}

The author of this paper would like to thank the reviewers for their valuable comments and effort to improve the manuscript.
8. Campa JM, Goldberg L. Exchange rate pass-through into import prices. Rev Econ Stat. (2005) 87:679-90. doi: 10.3386/w11632

9. Devereux MB, Yetman J. Price adjustment and exchange rate pass-through. $J$ Int Money Finan. (2010) 29:181-200. doi: 10.1016/j.jimonfin.2008.12.009

10. Mishkin FS. Exchange Rate Pass-Through and Monetary Policy. Cambridge, MA: National Bureau of Economic Research Working Papers (2008).

11. Gopinath G, Itskhoki O. Frequency of price adjustment and pass-through. $Q$ J Econ. (2010) 125:675-727. doi: 10.1162/qjec.2010.125.2.675

12. Taylor J. Low inflation, pass-through and the pricing power of firms. Eur Econ Rev. (2000) 44:1389-408. doi: 10.1016/S0014-2921(00)00037-4

13. Alptekin V, Yilmaz KÇ, Taş T. Döviz kurundan fiyatlara geçis etkisi: Türkiye örnegi. Selçuk Üniversitesi Sosyal Bilimler Enstitüsü Dergisi. (2016) 35:19. Available online at: http://dergisosyalbil.selcuk.edu.tr/susbed/article/view/ 1206

14. McCarthy J. Pass-Through of Exchange Rates and Import Prices to Domestic Inflation in Some Industrialized Economies. New York, NY: FRB of New York Staff Report 111 (2000). doi: 10.2139/ssrn.249576 
15. Ito $\mathrm{T}$, Sato $\mathrm{K}$. Exchange rate changes and inflation in post-crisis asian economies: vector autoregression analysis of the exchange rate pass-through. J Money Credit Bank. (2006) 40:1407-38. doi: 10.1111/j.1538-4616.2008.00165.x

16. Helmy O, Fayed M, Hussien K. Exchange rate pass-through to inflation in Egypt: a structural VAR approach. Rev Econ Polit Sci. (2018) 3:2-19. doi: 10.1108/REPS-07-2018-001

17. Leigh D, Rossi M. Exchange Rate Pass Through in Turkey. Washington, DC: IMF Working Paper. WP/02/204 (2002).

18. Ponomarev I, Trunin P, Ulyukaev A. Exchange rate passthrough in Russia. Prob Econ Transit. Tokyo (2016) 58:54-72. doi: 10.1080/10611991.2016.1162046

19. Ito T, Sato K. Exchange Rate Pass-Through and Domestic Inflation: A Comparison Between East Asia and Latin American Countries. Research Institute of Economy, Trade and Industry, RIETI Discussion Papers, 7040 (2007).

20. Kara H, Ögünç F. Döviz kuru ve ithalat fiyatlarinin yurt içi fiyatlara etkisi. Iktisat Işletme ve Finans. (2012) 27:9-28. doi: 10.3848/iif.2012.317.3396
21. Kaygisiz AD. Döviz kuru dalgalanmalarinin enflasyon üzerindeki geçiş etkisi: Türkiye örnegi. Int Rev Econ Manag. (2018) 6:117-37. Available online at: https://dergipark.org.tr/tr/download/article-file/618016

22. Dereli DD. Türkiye'de döviz kuru ile enflasyon arasindaki ilișkinin analizi (2005-2017). Electron Turk Stud. (2018) 13:137-50. doi: $10.7827 /$ TurkishStudies.14427

Conflict of Interest: The author declares that the research was conducted in the absence of any commercial or financial relationships that could be construed as a potential conflict of interest.

Copyright (C) 2020 Kotil. This is an open-access article distributed under the terms of the Creative Commons Attribution License (CC BY). The use, distribution or reproduction in other forums is permitted, provided the original author $(s)$ and the copyright owner(s) are credited and that the original publication in this journal is cited, in accordance with accepted academic practice. No use, distribution or reproduction is permitted which does not comply with these terms. 